\title{
Physico-chemical Properties, Mineral Matter, Organic Acid, Amino Acid, and Plant Hormones Content of Goji Berry (Lycium barbarum L.) Grown in Turkey
}

\author{
Rabia Talay ${ }^{1, a}$, Ümmügülsüm Erdoğan ${ }^{1, b, *}$, Metin Turan $^{2, c}$ \\ ${ }^{1}$ Department of Food Engineering, Faculty of Engineering, Bayburt University, 69000 Bayburt, Turkey \\ ${ }^{2}$ Yeditepe University, Faculty of Engineering and Architecture, Department of Genetic and Bioengineering, 34755 Istanbul, Turkey
} ${ }^{*}$ Corresponding author

\begin{tabular}{|c|c|}
\hline A R T I C LE I N F O & B S T R A C T \\
\hline $\begin{array}{l}\text { Keywords: } \\
\text { Goji berry } \\
\text { Lycium barbarum L. } \\
\text { Mineral matter }\end{array}$ & $\begin{array}{l}\text { With high nutritional value, goji berry is an important fruit for human nutrition and health. Goji } \\
\text { berry cultivation is done widely in many countries, farming has become widespread in recent years } \\
\text { in Turkey. In study grown goji berry (Lycium barbarum } \mathrm{L} \text {.) in Turkey are determined the physical } \\
\text { and chemical characteristics of fruit (pH, titration acidity, dry matter content, ash content, water } \\
\text { activity ( } \mathrm{a}_{\mathrm{w}} \text { ) value, protein content, HMF content, total phenolic content, total sugar content, } \\
\text { reducing sugar content, sucrose content, colour values, mineral contents, organic acid contents, } \\
\text { amino acid contents and some plant hormone content). Goji berry fruits have pH value } 5.18 \text {, titration } \\
\text { acidity value } 2.16 \% \text {, dry matter content } 89.40 \% \text {, ash content } 4.30 \% \text {, water activity (aw) value } 0.35 \text {, } \\
\text { protein content } 13.18 \% \text {, HMF content } 9.38 \mathrm{mg} / \mathrm{kg} \text {, total phenolic content } 9.05 \mathrm{mg} \mathrm{GAE} / \mathrm{g} \text {, total } \\
\text { sugar content } 59.26 \% \text {, decreasing sugar content } 57.35 \% \text {, sucrose content } 1.90 \%, L^{*} \text { value } 40.33, a^{*} \\
\text { value } 22.97, b^{*} \text { value } 33.00, \mathrm{C}^{*} \text { value } 40.21, \mathrm{H}^{\circ} \text { value } 55.15 \text {. In addition, the mineral content, organic } \\
\text { acid content, amino acid content and some plant hormones of goji berry fruits were determined by } \\
\text { analysis. }\end{array}$ \\
\hline
\end{tabular}

Organic acid

Amino acid

http://orcid.org/0000-0001-5988-3758

\section{Introduction}

Medicinal plants are used in the treatment of many diseases (Akgül et al., 2020; Pehlivan et al., 2021). In this sense, goji berry also has a special importance. Goji berry has long played important roles, especially in Traditional Chinese Medicine (Shahrajabian et al., 2020). Goji berry, which belongs to the Lycium genus of the Solanaceae family, includes about 80 species (Levin and Miller, 2005). All these species are plants in the form of deciduous perennial shrubs, which have a fairly similar morphology and structure (Qian et al., 2017). In addition, goji berry is also referred to as goji or wolfberry in the literature. Lycium is distributed in subtropical regions in temperate regions of South America, North America, Southern Africa, Eurasia and Australia (Fukuda et al., 2001). Lycium fruits (Lycium barbarum, Lycium chinense) are mostly grown and distributed in Northwest China (Yossa Nzeuwa et al., 2019). Goji berry is used as a functional food in many countries of East Asia, Europe and North America (Ferraz et al., 2019). Goji berry fruits are used as a traditional herbal tea in Asia (Sun et al., 2017). Apart from herbal tea, it is also widely used in Chinese soups. In addition, this fruit is preferred in production areas such as tincture, wine and juice (Ma et al., 2019). Scientific analysis of goji berry components began in the 1970s (Chen et al., 2018) and the fruit was found to have high nutritional value (Amagase et al., 2009). Goji berry, a rich source of antioxidant compounds, is important for health. Goji berry antioxidants have many beneficial effects in maintaining health by reducing oxidative stress (Donno et al., 2015). As a result of modern medicine, nutrition and pharmacology studies, it has been determined that goji berry fruits, leaves and roots contain polysaccharides, vitamins, amino acids and trace elements (Ahn et al., 2014). It is known that dried goji berry $(100 \mathrm{~g})$ contain approximately $10.2 \mathrm{~g}$ of protein, 4.4 $\mathrm{g}$ of fat, $61.3 \mathrm{~g}$ of total carbohydrate, $184.2 \mathrm{mg}$ of total carotenoid, $101.3 \mathrm{mg}$ of $\mathrm{Ca}, 45.9 \mathrm{mg}$ of $\mathrm{Mg}$ (Niro et al., 2017). In this study, it was aimed to determine some physical and chemical contents of L. barbarum, which is grown in our country, is classified as functional foods and has an area of use as a natural antioxidant additive. 


\section{Materials and Methods}

\section{Plant material}

Fully ripened NQ1 fruits (L. barbarum) in September 2020 in Bor (Niğde, Turkey) were collected from plants. The fruits were left to dry in the oven at $40^{\circ} \mathrm{C}$ for 48 hours. The dried fruits were ground, sieved and stored in jars at $4^{\circ} \mathrm{C}$ until analysis.

\section{Determination of titration acidity and $\mathrm{pH}$ value}

$\mathrm{pH}$ value was done by using $\mathrm{pH}$ meter calibrated with pH 7.0 buffer. Titratable acidity was determined potentiometrically by titrating the sample with $0.1 \mathrm{NaOH}$ until the $\mathrm{pH}$ reached 8.1 and expressed as $\mathrm{g} / 100 \mathrm{~g}$ anhydrous citric acid (Cunnif, 1999).

\section{Determination of dry matter and ash content}

Dry matter content was determined as using an air oven at $104^{\circ} \mathrm{C}$. The dry matter content obtained was calculated using the formula below (Cunnif, 1999). Dry matter content was determined according to the formula below.

$$
\text { Dry matter }(\%)=\frac{\text { Final weight }- \text { Tare weight }}{\text { Weight of sample }} \times 100
$$

Ash content was determined by burning the samples in an ash furnace at $550{ }^{\circ} \mathrm{C}$ until they became white ash. The ash content obtained was calculated using the formula below (Cunnif, 1999). Ash content was determined according to the formula below.

$$
\text { Ash }(\%)=\frac{\text { Weight of ash }}{\text { Weight of sample }} \times 100
$$

Determination of water activity $\left(a_{w}\right)$ value

Water activity was measured three times per treatment using an Novasina Labmaster water activity meter.

\section{Determination of protein content}

The protein quantity was obtained by Kjeldahl method. The protein content obtained was calculated using the formula below (Cunnif, 1999).

$$
\% \text { Protein }=\% \text { Total nitrogen } \times 6.25
$$

\section{Determination of HMF content}

Hydroxymethylfurfural (HMF) was identified by measuring the absorbance variation of the samples by barbituric acid and p-toluidine, using a spectrophotometer (Winkler, 1955).

\section{Determination of total phenolic content}

The phenolic matter content was determined in accordance with Folin-Ciocalteu method (Gulcin et al., 2002).

\footnotetext{
Determination of total sugar, reducing sugar and sucrose content

Total sugar, reducing sugar and sucrose contents were determined by the Lane-Eynon method (Lane and Eynon, 1934). In this method, it is based on the principle of reducing the copper- 2 oxide in the Fehling solution of invert sugar to the water-insoluble copper-1 oxide.
}

\section{Determination of colour values}

Colour values $\left(L^{*}, a^{*}\right.$ and $\left.b^{*}\right)$ of the samples were measured using Minolta Reflectance Chroma Meter CR300. Using $L^{*}, a^{*}$ and $b^{*}$ values, colour density $\left(\mathrm{C}^{*}\right)$ and hue angle $\left(\mathrm{H}^{\circ}\right)$ were calculated according to the formulas below (Pathare et al., 2013).

$$
\begin{aligned}
& \mathrm{C}^{*}=\sqrt{\mathrm{a}^{* 2}+\mathrm{b}^{* 2}} \\
& \mathrm{H}^{\circ}=\tan ^{-1} b^{*} / a^{*}
\end{aligned}
$$

\section{Determination of mineral contents}

Firstly, the samples were washed with distilled water and cleaning procedure was carried out. The samples were then oven-dried at $65^{\circ} \mathrm{C}$ until their weight was constant. Finally, the samples ground and sieved through a 50-mesh screen. Kjeldahl method and a Vapodest 10 Rapid Kjeldahl Distillation Unit (Gerhardt, Germany) were used to determine total $\mathrm{N}$ (Bremner and Mulvaney, 1982). After extraction methods, tissue $\mathrm{B}, \mathrm{Ca}, \mathrm{Cu}, \mathrm{Fe}, \mathrm{K}, \mathrm{Mg}, \mathrm{Mo}, \mathrm{N}$, $\mathrm{Na}, \mathrm{P}$ and $\mathrm{Zn}$ were determined with an inductively coupled plasma spectrophotometer Perkin-Elmer Optima 2100 DV ICP/OES (Perkin-Elmer, USA).

\section{Determination of organic acids}

For organic acid analysis, $10 \mathrm{~mL}$ deionized water was added to sample $(1 \mathrm{~g})$, solution was then homogenized with ultraturraks. After centrifuging at $1200 \mathrm{rpm}$ for $50 \mathrm{~min}$, supernatants were filtered. In vials, organic acid determined by using HPLC (Shi et al., 2006).

\section{Determination of amino acids}

To determine amino acid analysis, $0.1 \mathrm{~N} \mathrm{HCl}$ added 1 $\mathrm{g}$ sample, homogenized with ultraturraks, and incubated in $4^{\circ} \mathrm{C}$ at $12 \mathrm{~h}$. After samples were centrifuged at $1200 \mathrm{rpm}$ for $50 \mathrm{~min}$, supernatants were filtered through $0.22 \mathrm{~m}$ (Millex Millipore). Then supernatants were transferred tovial and vials for amino acid acid analysis in HPLC as de-scribed by Aristoy and Toldra (1991) and Antoine et al. (1999).

\section{Determination of some plant hormones}

Extraction and purification processes for hormone analysis It was made according to Davis et al. (1995). Indole acetic acid (IAA) gibberellic acid (GA), salicylic (SA) and abscisic acid (ABA) high performance liquid chromatography in analysis (HPLC) has been used (Horgan and Kramers, 1979, Morris et al., 1990, Takahashi, 1986). Abscisic acid (ABA), gibberellic acid and indole-3-acetic acid (IAA), were determined with $13 \%$ acetonitrile $(\mathrm{pH} 4.98)$ as the mobile phase.

\section{Statistical analysis}

Results of the research were analysed for statistical significance by analysis of variance.

\section{Result and Discussion}

\section{Titration acidity and $\mathrm{pH}$ value}

Titration acidity value, $\mathrm{pH}$ value, dry matter content, ash content and total phenolic content, which are important indicators of sensory quality of goji berries, are shown in 
Table 1 . The $\mathrm{pH}$ and titratable acidity of goji berries were determined as $5.18 \%$ and $2.16 \%$, respectively. Zhang et al. (2016) determined the titratable acidity of goji berry fruit 0.8 $1.4 \%$, Ilić et al. (2020) 0.70-0.89\%, Catav and Purlak (2020) determined it as $0.05-0.19$. It is seen in our study that the titration acidity value is within the range of the reported values. The $\mathrm{pH}$ value of goji fruit has been reported as 4.985.71 Catav and Prrlak (2020) and 4.71 Ilić et al. (2020).

\section{Dry matter and ash content}

The dry matter and ash content of goji berries were $89.40 \%$ and $4.30 \%$, respectively. Dry matter content Pedro et al. (2019) reported it as $84.71 \%$, Niro et al. (2017) 90.7\%. It is seen that the dry matter content in our study is approximately the similar with the results reported. Ash content Ilić et al. (2020) reported it as $0.84 \%$, Pedro et al. (2019) $3.01 \%$ and Niro et al. (2017) 3.4\%. It appears that the ash content in our study is higher than the results reported by.

\section{Water activity $\left(a_{w}\right)$ value}

Water activity of goji berry was determined as 0.35 (Table 1). Pedro et al. (2019) reported the water activity value of goji berry 0.37 , it is seen that the water activity value in our study is approximately the similar with the results reported.

\section{Protein content}

In our study, the protein content of goji berry was determined as $13.18 \%$. In similar studies, the content of protein in fresh goji berry Ilić et al. (2020) 1.98\%, in dried goji berry Niro et al. (2017) 10.2\%, in dried fruit Endes et al. (2015) $8.9 \%$, in lyophilized goji berry Pedro et al. (2019) $9.72 \%$, Covaci et al. (2020) $3.5-20.3 \%$ found it to be. Our conclusion is consistent with the data from previous studies, that goji berries have significant potential to provide the required daily protein for adults $(0.8 \mathrm{~g} / \mathrm{kg}$ body weight).

\section{HMF content}

HMF content of goji berry was determined as 9.38 $\mathrm{mg} / \mathrm{kg}$. At the end of any heating or storage applied to foods containing carbohydrates; depending on the temperature and time, a small or large amount of HMF is always formed.

\section{Total phenolic content}

Quantification of total phenols is especially important for nutraceutical use of foods. In our study, the total phenolic content of goji berry was determined as $9.05 \mathrm{mg}$ GAE/g. Islam et al. (2017) 2.17-9.01 mg GAE/g, Ozkan et al. (2018) $9.04 \mathrm{mg} \mathrm{GAE} / \mathrm{g}$, Jeepipalli and Xu (2020) 86.88 $\mathrm{mg} \mathrm{GAE} / \mathrm{g}$ and $56.97 \mathrm{mg} \mathrm{GAE} / \mathrm{g}$ in fresh and dried goji berries, respectively, Ilić et al. (2020) $162.4 \mathrm{mg} \mathrm{GAE} / 100$ $\mathrm{g}$ has been reported to have a total phenolic amount of. When the previously published data are compared with our results, the differences observed in the contents of phenolic substances can be explained by different climatic and soil factors affecting plant growth with varieties.

\section{Total sugar, reducing sugar and sucrose content}

The taste and quality of fruits mainly depend on sugars, organic acids, amino acids. Total sugar, reducing sugar and sucrose content of goji berry were determined as 59.26, 57.35 and 1.90 , respectively (Table 1 ). The total sugar content of goji berries, Li et al. (2017) 40.72-60.73\% in 114 samples, Tang and Liu (2013) found it to be 40.70-53.78\% in 40 samples. Wang et al. (2019) reported that the concentrations of sucrose varied between $3.8-5 \mathrm{mg} / \mathrm{g}$ and glucose and fructose concentrations between 30-39 and 50$55 \mathrm{mg} / \mathrm{g}$, respectively. Donno et al. (2019) determined the sucrose content of goji berry as $2.77 \mathrm{~g} / 100 \mathrm{~g}$. Our result is between these values.

\section{Colour values}

In our study, $L^{*}, a^{*}, b^{*}, \mathrm{C}^{*}$ and $\mathrm{H}^{\mathrm{o}}$ values of goji berries were determined as 40.33, 22.97, 33.00, 40.21 and 55.15, respectively. Song et al. (2018) reported $L^{*}$ value as 24.5-33.5, $a^{*}$ value as $12.5-26.1, b^{*}$ value as 5.82-13.0; Pedro et al. (2019) reported $34.83 L^{*}, 31.82 a^{*}, 34.99 b^{*}$ in dried goji berry.

\section{Mineral contents}

Goji berry (L. barbarum) is known for their nutritional potential as a great source of trace metals (e.g., copper, zinc and manganese) which are present in the form of highly bioaccessible compounds (Wojcieszek et al., 2017). The content of both macro and microelements in goji berries is shown in Table 2. Potassium (30871 mg/kg) has been identified as the dominant element. Molibden $(5.93 \mathrm{mg} / \mathrm{kg})$ and sodium $(2.44 \mathrm{mg} / \mathrm{kg})$ became the least abundant nutrient. Endes et al. (2015) and Niro et al. (2017) reported slightly different results from ours. It is important to emphasize that the mineral content of fruits depends on the soil properties in which they are grown, the physiology of the plant, the water source composition and the fertilizers, insecticides, pesticides and fungicides used in the fields.

\section{Organic acids}

Goji berry is a rich source of bioactive compounds with functional properties. Among the organic acids we analysed, succinic acid was found to have the highest value of $17.85 \mathrm{ng} / \mu \mathrm{L}$, and maleic acid to have the lowest value of $0.19 \mathrm{ng} / \mu \mathrm{L}$ (Table 2).

Table 1. Averages of some physical and chemical parameters of goji berry

\begin{tabular}{l|lll}
\hline Parameters & Averages & Parameters & Averages \\
\hline $\mathrm{pH}$ & $5.18 \pm 0.01$ & Total sugar $(\%)$ & $59.26 \pm 0.97$ \\
Titration acidity $(\%)$ & $2.16 \pm 0.04$ & Reducing sugar $(\%)$ & $57.35 \pm 1.27$ \\
Dry matter (\%) & $89.40 \pm 1.20$ & Sucrose $(\%)$ & $1.90 \pm 0.39$ \\
Ash $(\%)$ & $4.30 \pm 0.11$ & $L^{*}$ & $40.33 \pm 0.53$ \\
Water activity $\left(\mathrm{a}_{\mathrm{w}}\right)$ & $0.35 \pm 0.00$ & $a^{*}$ & $22.97 \pm 0.34$ \\
Protein $(\%)$ & $13.18 \pm 0.01$ & $b^{*}$ & $33.00 \pm 1.03$ \\
$\mathrm{HMF}(\mathrm{mg} / \mathrm{kg})$ & $9.38 \pm 0.58$ & $\mathrm{C}^{*}$ & $40.21 \pm 1.04$ \\
TPC $(\mathrm{mg}$ GAE/g) & $9.05 \pm 0.21$ & $\mathrm{H}^{\circ}$ & $55.15 \pm 0.46$ \\
\hline
\end{tabular}


Table 2. Averages of minerals and organic acids contents of goji berry

\begin{tabular}{l|clc}
\hline \multicolumn{1}{c|}{ Minerals } & Averages $(\mathrm{mg} / \mathrm{kg})$ & \multicolumn{1}{c}{ Organic acids } & Averages $(\mathrm{ng} / \mu \mathrm{L})$ \\
\hline $\mathrm{B}$ & $18.01 \pm 1.51$ & Butyric acid & $2.78 \pm 20.25$ \\
$\mathrm{Ca}$ & $10613 \pm 1.10$ & Citric acid & $2.61 \pm 10.30$ \\
$\mathrm{Cu}$ & $58.29 \pm 0.69$ & Fumaric acid & $2.10 \pm 15.41$ \\
$\mathrm{Fe}$ & $289.23 \pm 1.15$ & Lactic acid & $17.03 \pm 16.14$ \\
$\mathrm{~K}$ & $30871 \pm 3.30$ & Maleic acid & $0.19 \pm 30.10$ \\
$\mathrm{Mg}$ & $2346 \pm 10.11$ & Malic acid & $6.21 \pm 18.27$ \\
$\mathrm{Mo}$ & $5.93 \pm 0.18$ & Malonic acid & $5.01 \pm 26.34$ \\
$\mathrm{~N}$ & $2.44 \pm 0.20$ & Oxalic acid & $6.00 \pm 19.51$ \\
$\mathrm{Na}$ & $452 \pm 1.15$ & Propionic acid & $3.38 \pm 36.48$ \\
$\mathrm{P}$ & $3591 \pm 14.26$ & Succinic acid & $17.85 \pm 41.36$ \\
$\mathrm{Zn}$ & $54.52 \pm 0.49$ & Tartaric acid & $2.17 \pm 38.15$ \\
\hline
\end{tabular}

Table 3. Averages of amino acids of goji berry

\begin{tabular}{l|clc}
\hline \multicolumn{1}{c|}{ Amino acids } & Averages $(\mathrm{pmol} / \mu \mathrm{L})$ & \multicolumn{1}{c}{ Amino acids } & Averages $(\mathrm{pmol} / \mu \mathrm{L})$ \\
\hline Alaine & $6182 \pm 0.51$ & Leucine & $1858 \pm 0.05$ \\
Arginine & $6848 \pm 1.40$ & Lysine & $2887 \pm 1.63$ \\
Asparagine & $11946 \pm 1.21$ & Methionine & $1134 \pm 1.40$ \\
Aspartate & $3115 \pm 0.22$ & Phenylalanine & $1604 \pm 0.71$ \\
Cysteine & $1091 \pm 0.93$ & Proline & $68 \pm 1.50$ \\
Glutamate & $1393 \pm 1.25$ & Sarcosine & $5361 \pm 2.05$ \\
Glutamine & $3711 \pm 1.09$ & Serine & $5231 \pm 1.23$ \\
Glycine & $2582 \pm 1.69$ & Threonine & $3286 \pm 0.76$ \\
Histidine & $1858 \pm 1.03$ & Tryptophan & $1652 \pm 1.22$ \\
Hydroxyproline & $1036 \pm 1.72$ & Tyrosine & $889 \pm 1.64$ \\
İsoluecine & $1323 \pm 1.07$ & Valine & $651 \pm 3.07$ \\
\hline
\end{tabular}

Table 4. Averages of some plant hormones of goji berry

\begin{tabular}{l|l}
\hline \multicolumn{1}{c|}{ Hormones } & \multicolumn{1}{c}{ Averages $(\mathrm{ng} / \mu \mathrm{L})$} \\
\hline Abscisic acid (ABA) & $0.35 \pm 1.48$ \\
Gibberellic acid & $139.31 \pm 2.54$ \\
Indole-3-acetic acid (IAA) & $21.71 \pm 0.95$ \\
\hline
\end{tabular}

\section{Amino acids}

The 22 amino acids content of goji berry is shown in Table 3. Goji berries contain a large number of amino acids. Asparagine $(11946 \mathrm{pmol} / \mu \mathrm{L})$, arginine $(6848 \mathrm{pmol} / \mu \mathrm{L})$, alaine $(6182 \mathrm{pmol} / \mu \mathrm{L})$, sarcosine $(5361 \mathrm{pmol} / \mu \mathrm{L})$, serine $(5231 \mathrm{pmol} / \mu \mathrm{L})$ and glutamine $(3711 \mathrm{pmol} / \mu \mathrm{L})$ at the highest level identified as amino acids found. The lowest values were determined in proline $(68 \mathrm{pmol} / \mu \mathrm{L})$, valine $(651 \mathrm{pmol} / \mu \mathrm{L})$ and tyrosine $(889 \mathrm{pmol} / \mu \mathrm{L})$. Zhao et al. (2020) reported amounts of histidine $(2.68-11.11 \mathrm{mg} / 100 \mathrm{~g})$, isoleucine (11.13-20.22 mg/100 g), leucine (12.30-34.47 mg/100 g), methionine $(0.71-3.99 \mathrm{mg} / 100 \mathrm{~g})$ valine $(3.98-8.76 \mathrm{mg} / 100 \mathrm{~g})$ and lysine (3.76-6.76 mg/100 g).

\section{Some plant hormones}

Hormones are the basic internal factors regulating the growth and development of the plant and have chemical properties. Some of the plant hormones determined in goji berry are shown in Table 4 . Abscisic acid, gibberellic acid and indole-3-acetic acid were found as $0.35 \mathrm{ng} / \mu \mathrm{L}, 139.31$ $\mathrm{ng} / \mu \mathrm{L}$ and $21.71 \mathrm{ng} / \mu \mathrm{L}$, respectively, in goji berry.

\section{Conclusion}

Goji berry is an important fruit with rich nutrient content with proven health benefits as well as nutritious properties. This study was conducted in the nutritional and chemical characterization L. barbarum grown in Turkey.
The results obtained from the determination of some mineral elements in goji berries indicate significant amounts of essential elements ( $\mathrm{K}>\mathrm{Ca}>\mathrm{P}>\mathrm{Mg}>\mathrm{Fe}$ ). Their chemical composition revealed asparagine as the dominant amino acid present, while succinic acid showed the largest amount in relation to organic acids. According to the results, it was seen that goji berry is a good choice to enrich the daily diet due to its nutritional and chemical composition. Goji berries grown in Turkey (L. barbarum) has proven to be an effective natural dietary supplement. Our results improve information on the composition and nutritional properties of dried goji berries grown in Turkey.

\section{References}

Ahn M, Park JS, Chae S, Kim S, Moon C, Hyun JW, Shin T. 2014. Hepatoprotective effects of Lycium chinense Miller fruit and its constituent betaine in $\mathrm{CCl}_{4}$-induced hepatic damage in rats. Acta Histochemica, 116(6): 1104-1112. doi: 10.1016/j.acthis.2014.05.004.

Akgül H, Korkmaz N, Dayangaç A, Sevindik M. 2020. Antioxidant potential of endemic Salvia absconditiflora. Turkish Journal of Agriculture-Food Science and Technology, 8(10): 2222-2224. doi: https://doi.org/ 10.24925/turjaf.v8i10.2222-2224.3697

Amagase H, Sun B, Borek C. 2009. Lycium barbarum (goji) juice improves in vivo antioxidant biomarkers in serum of healthy adults. Nutrition Research, 29(1): 19-25. doi: 10.1016/j.nutres.2008.11.005 
Antoine F, Wei C, Littell R, Marshall M. 1999. HPLC method for analysis of free amino acids in fish using o-phthaldialdehyde precolumn derivatization. Journal of Agricultural and Food Chemistry, 47(12): 5100-5107. doi: 10.1021/jf990032+

Aristoy MC, Toldra F. 1991. Deproteinization techniques for HPLC amino acid analysis in fresh pork muscle and dry-cured ham. Journal of Agricultural and Food Chemistry, 39(10): 1792-1795. doi:10.1021/jf00010a020

Bremner J, Mulvaney C. 1982. Nitrogen-total Methods of soil analysis. Part 3-chemical methods. Soil Science of America and American Society of Agronomy, SSSA Page 1085. ISBN 978-0-89118-072-2.

Catav N, Prrlak L. 2020. A Research on adaptation of goji berry (Lycium barbarum L.) in the Konya conditions. Alatarım, 19(1): 1-8.

Chen J, Chao CT, Wei X. 2018. Breeding and Health Benefits of Fruit and Nut Crops. IntechOpen. ISBN 978-1-78923-272-1.

Covaci E, Senila M, Leopold LF, Olah NK, Cobzac C, IvanovaPetropulos V, Balabanova B, Cadar O, Becze A, Ponta M. 2020. Characterization of Lycium barbarum L. berry cultivated in North Macedonia: A chemometric approach. Journal of Berry Research, 10(2): 223-241. doi: 0.3233/JBR190450

Cunnif P. 1999. Association of official analytical chemists. Official and tentative methods of the AOAC international. 16th Edition, 5th Reversion, AOAC International, Gaithersburg, MD. ISBN 0-93558-454-4.

Davis D, Liu X, Segaloff DL. 1995. Identification of the sites of $\mathrm{N}$-linked glycosylation on the follicle-stimulating hormone (FSH) receptor and assessment of their role in FSH receptor function. Molecular Endocrinology, 9(2): 159-170. doi:10.1210/mend.9.2.7776966

Donno D, Beccaro GL, Mellano MG, Cerutti AK, Bounous G. 2015. Goji berry fruit (Lycium spp.): antioxidant compound fingerprint and bioactivity evaluation. Journal of Functional Foods, 18: 1070-1085. doi: 10.1016/j.jff.2014.05.020.

Donno D, Mellano MG, Riondato I, De Biaggi M, Andriamaniraka H, Gamba G, Beccaro GL. 2019. Traditional and unconventional dried fruit snacks as a source of healthpromoting compounds. Antioxidants, 8(9): 396. doi: 10.3390/antiox8090396

Endes Z, Uslu N, Özcan MM, Er F. 2015. Physico-chemical properties, fatty acid composition and mineral contents of goji berry (Lycium barbarum L.) fruit. Journal of Agroalimentary Processes and Technologies, 21(1): 36-40.

Ferraz JDRS, Macedo JL, Silva DJS, Sampaio LVA. 2019. Goji berry: nutritional properties and benefits for human health. Research, Society and Development, 8(4): 284934. doi: $10.33448 /$ rsd-v8i4.934

Fukuda T, Yokoyama J, Ohashi H. 2001. Phylogeny and biogeography of the genus Lycium (Solanaceae): inferences from chloroplast DNA sequences. Molecular Phylogenetics and Evolution, 19(2): 246-258. doi: 10.1006/mpev.2001.0921

Gulcin İ, Oktay M, Kufrevioğlu Öİ, Aslan A. 2002. Determination of antioxidant activity of lichen Cetraria islandica (L) Ach. Journal of Ethnopharmacology, 79(3): 325-329. doi: 10.1006/mpev.2001.0921

Horgan R, Kramers MR. 1979. High-performance liquid chromatography of cytokinins. Journal of Chromatography A, 173(2): 263-270. doi: 10.1016/S0021-9673(00)92295-7

Ilić T, Dodevska M, Marčetić M, Božić D, Kodranov I, Vidović B. 2020. Chemical characterization, antioxidant and antimicrobial properties of goji berries cultivated in Serbia. Foods, 9(11): 1614. doi: 10.3390/foods9111614.

Islam T, Yu X, Badwal TS, Xu B. 2017. Comparative studies on phenolic profiles, antioxidant capacities and carotenoid contents of red goji berry (Lycium barbarum) and black goji berry (Lycium ruthenicum). Chemistry Central Journal, 11(1): 59. doi: 10.1186/s13065-017-0287-z
Jeepipalli S, Xu B. 2020. Phytochemicals in Goji Berries, pp. 225-232, CRC Press. ISBN 9-780-36707-634-4

Lane JH, Eynon L. 1934. Determination of reducing sugars by Fehling's solution with methylene blue indicator. Ed. N. Rodger.

Levin RA, Miller JS. 2005. Relationships within tribe Lycieae (Solanaceae): paraphyly of Lycium and multiple origins of gender dimorphism. American Journal of Botany, 92(12): 2044-2053. doi: 10.3732/ajb.92.12.2044

Li Q, Yu X, Gao JM. 2017. A novel method to determine total sugar of goji berry using FT-NIR spectroscopy with effective wavelength selection. International Journal of Food Properties, 20: 478-488. doi: 10.1080/10942912.2017.1299759

Ma ZF, Zhang H, Teh SS, Wang CW, Zhang Y, Hayford F, Wang L, Ma T, Dong Z, Zhang Y. 2019. Goji berries as a potential natural antioxidant medicine: An insight into their molecular mechanisms of action. Oxidative Medicine And Cellular Longevity, doi: 10.1155/2019/2437397

Morris JW, Doumas P, Morris RO, Zaerr JB. 1990. Cytokinins in vegetative and reproductive buds of Pseudotsuga menziesii. Plant Physiology, 93(1): 67-71. doi: 10.1104/pp.93.1.67

Niro S, Fratianni A, Panfili G, Falasca L, Cinquanta L. Alam, MR. 2017. Nutritional evaluation of fresh and dried goji berries cultivated in Italy. Italian Journal of Food Science, 29(3). doi: 10.14674/1120-1770/ijfs.v649

Ozkan EE, Ozden TY, Toplan GG, Mat A. 2018. Phenolic content and biological activities of Lycium barbarum L. (Solanaceae) fruits (Goji berries) cultivated in Konya, Turkey. Tropical Journal of Pharmaceutical Research, 17(10): 2047-2053. doi: 10.4314/tjpr.v17i10.22

Pathare PB, Opara UL, Al-Said FAJ. 2013. Colour measurement and analysis in fresh and processed foods: a review. Food and Bioprocess Technology, 6(1): 36-60. doi: 10.1007/s11947012-0867-9

Pedro AC, Sánchez-Mata MC, Pérez-Rodríguez ML, Cámara M, López-Colón JL, Bach F, Bellettini M, Haminiuk CWI. 2019. Qualitative and nutritional comparison of goji berry fruits produced in organic and conventional systems. Scientia Horticulturae, 257: 108660. doi: 10.1016/j.scienta.2019.108660

Pehlivan M, Mohammed FS, Şabik AE, Kına E, Dogan M, Yumrutaş Ö, Sevindik M. 2021. Some Biological activities of ethanol extract of Marrubium globosum. Turkish Journal of Agriculture-Food Science and Technology, 9: 1129-1132. doi: https://doi.org/10.24925/turjaf.v9i6.1129-1132.4382

Qian D, Zhao Y, Yang G, Huang L. 2017. Systematic review of chemical constituents in the genus Lycium (Solanaceae). Molecules, 22(6): 911. doi: 10.3390/molecules22060911

Shahrajabian MH, Wenli SUN, Cheng Q. 2020. A short review of goji berry, ginger, ginseng and astragalus in traditional Chinese and Asian medicine. Black Sea Journal of Health Science, 3(2): 36-45.

Shi L, Chen B, Wang Z, Elias DA, Mayer MU, Gorby YA, Ni S, Lower BH, Kennedy DW, Wunschel DS. 2006. Isolation of a high-affinity functional protein complex between OmcA and MtrC: two outer membrane decaheme c-type cytochromes of Shewanella oneidensis MR-1. Journal of Bacteriology, 188(13): 4705-4714. doi: 10.1128/JB.01966-05

Song H, Bi J, Chen Q, Zhou M, Wu X, Song J. 2018. Structural and health functionality of dried goji berries as affected by coupled dewaxing pre-treatment and hybrid drying methods. International Journal of Food Properties, 21(1): 2527-2538. doi: 10.1080/10942912.2018.1536148

Sun Y, Rukeya J, Tao W, Sun P, Ye X. 2017. Bioactive compounds and antioxidant activity of wolfberry infusion. Scientific Reports, 7(1): 1-8. doi: 10.1038/srep40605

Takahashi N. 1986. Chemistry of plant hormones, CRC Press.

Tang L, Liu, D. 2013. Quantitative analysis of Lycium barbarum L. composition based on near infrared spectrum. Modern Food Science and Technology, 29: 2306-2310. 
Wang T, Wright D, Xu H, Yang Y, Zheng R, Shi J, Chen R, Wang L. 2019. Expression patterns, activities and sugar metabolism regulation of sucrose phosphate synthase, sucrose synthase, neutral invertase and soluble acid invertase in different goji cultivars during fruit development. Russian Journal of Plant Physiology, 66: 29-40. doi: 10.1134/S1021443719010199

Winkler O. 1955. Beitrag zum nachweis und zur bestimmung von oxymethylfurfurol in honig und kunsthonig. Zeitschrift für Lebensmittel-Untersuchung und Forschung, 102(3): 161167.

Wojcieszek J, Kwiatkowski P, Ruzik L. 2017. Speciation analysis and bioaccessibility evaluation of trace elements in goji berries (Lycium barbarum L.). Journal of Chromatography A, 1492: 70-78. doi: 10.1016/j.chroma.2017.02.069
Yossa Nzeuwa IB, Guo B, Zhang T, Wang L, Ji Q, Xia H, Sun G. 2019. Comparative metabolic profiling of Lycium fruits (Lycium barbarum and Lycium chinense) from different areas in China and from Nepal. Journal of Food Quality, doi: https://doi.org/10.1155/2019/4396027

Zhang Q, Chen W, Zhao J, Xi W. 2016. Functional constituents and antioxidant activities of eight Chinese native goji genotypes. Food Chemistry, 200: 230-236. doi: 10.1016/j.foodchem.2016.01.046

Zhao D, Li S, Han X, Li C, Ni Y, Hao J. 2020. Physico-chemical properties and free amino acids profiles of six wolfberry cultivars in Zhongning. Journal of Food Composition and Analysis, 88: 103460. doi: 10.1016/j.jfca.2020.103460 